\title{
A MARKETING MIX MODEL FOR A COMPLEX AND TURBULENT ENVIRONMENT
}

\author{
R B Mason, Department of Marketing, Durban University of Technology, South Africa; G Staude, \\ Rhodes Investec Business School, Rhodes University, Grahamstown. South Africa.
}

\begin{abstract}
Purpose: This paper is based on the proposition that the choice of marketing tactics is determined, or at least significantly influenced, by the nature of the company's external environment. It aims to illustrate the type of marketing mix tactics that are suggested for a complex and turbulent environment when marketing and the environment are viewed through a chaos and complexity theory lens.
\end{abstract}

Design/Methodology/Approach: Since chaos and complexity theories are proposed as a good means of understanding the dynamics of complex and turbulent markets, a comprehensive review and analysis of literature on the marketing mix and marketing tactics from a chaos and complexity viewpoint was conducted. From this literature review, a marketing mix model was conceptualised.

Findings: A marketing mix model considered appropriate for success in complex and turbulent environments was developed. In such environments, the literature suggests destabilising marketing activities are more effective, whereas stabilising type activities are more effective in simple, stable environments. Therefore the model proposes predominantly destabilising type tactics as appropriate for a complex and turbulent environment such as is currently being experienced in South Africa.

Implications: This paper is of benefit to marketers by emphasising a new way to consider the future marketing activities of their companies. How this model can assist marketers and suggestions for research to develop and apply this model are provided. It is hoped that the model suggested will form the basis of empirical research to test its applicability in the turbulent South African environment.

Originality/Value: Since businesses and markets are complex adaptive systems, using complexity theory to understand how to cope in complex, turbulent environments is necessary, but has not been widely researched. In fact, most chaos and complexity theory work in marketing has concentrated on marketing strategy, with little emphasis on individual tactics and even less on the marketing mix as a whole. Therefore, this paper can be viewed as an important foundation for a new stream of research using chaos and complexity theory to better understand marketing mixes and the choice of marketing tactics for complex and turbulent business environments.

Key words and phrases: Complexity theory, chaos theory, external environment, marketing mix, marketing tactics.

\section{INTRODUCTION}

The environment of business on a global basis is becoming extremely complex and has been experiencing unprecedented continuous, rapid change (Ahmed et al., 1996:562; Gilmore \& Pine, 1997:91; Doherty \& Delener, 2001:66; Burnes, 2005:73 and Yadav, Swami \& Pal, 2006:57).This escalating rate of change is being experienced in South Africa to an equal and probably greater extent than elsewhere (Forsdick, 1995:11; Lamb et al., 2004:xvii and Harris, 2005:24).Traditional methods for handling change, such as strategic planning, scenario planning, strategic visioning, market research and forecasting, are becoming inadequate to cope with the speed and volume of continuous change and with the unpredictability of discontinuous change (Wall \& Wall, 1995:7; Lane \& Maxfield, 1996:215; Edgar \& Nisbet, 1996:8; Siggelkow \& Rivkin, 2005:101 and Aktouf, Chernoufi \& Holford, 2005:181). Understanding and finding new ways of coping with such continuous and unpredictable changes have, therefore, become necessary.

Marketers have to be able to anticipate, cope with and adapt to changes in the external environment. In a stable and predictable business environment, this coping and adapting is relatively easy, but as the environment becomes more complex, and changes happen more rapidly, coping and adapting becomes more problematic and difficult. One way of finding new ways to cope with this volatility is by applying theories from outside the field of marketing in order to obtain a fresh insight into the problem (Coffey \& Atkinson, 1996:158). An ever-increasing number of authors believe that the new sciences, specifically chaos and complexity theories, can provide a better understanding of the current 
organisational and marketing environment (McKelvey, 2003:314 and Van Uden, 2005:65). For example, Wollin and Perry (2004:569) maintain that:

"...Complexity theory in the form of complex adaptive systems has implications for marketing managers as a holistic, self-consistent framework for understanding profound forces within a market and provides some guides for action when operating within such a system."

\section{PURPOSE OF THE PAPER}

In order to address the problem outlined above, this paper reports on a secondary analysis of literature covering the application of chaos and complexity theory in the marketing field, and the development from this analysis of a marketing mix model that proposes marketing tactics suitable for complex and turbulent marketing environments. The focus is specifically on the application of marketing tactics in complex and turbulent external environments because such environments are prevalent in South Africa and the rest of the African continent.

After briefly explaining how the study was conducted, the paper presents evidence of the state of business environments in terms of complexity and turbulence and then gives a brief overview of chaos and complexity theories. Then the relevance of chaos and complexity theories to marketing are discussed, and what the literature has to say about each of the major marketing tactics is presented. From the summary of the literature, a model of the proposed marketing tactics relevant for a complex and turbulent business environment is presented. Finally, the implications of this model for marketers and suggestions for further research are provided.

\section{METHOD}

Since this is a relatively poorly researched field, a broad methodology was used to gather and analyse the literature, which was not restricted to scholarly material. Broad searches via scholarly databases was done, but was supplemented with comprehensive Internet searches, material from newspapers and magazines, and numerous books aimed at the lay manager. Management consultants have conducted much of the work in the field and this has also been used, albeit with the requisite care and scepticism. The data thus gathered was analysed using typical qualitative approaches such as a deconstruction of the relevant articles, and a reconstruction into the themes upon which this article is based. The believability and trustworthiness of the outcomes of this analysis is based on theory and data triangulation, which Babbie and Mouton (1998:277) suggest provides credibility.

\section{LITERATURE REVIEW}

In this section of the paper, a literature review of the literature relevant to marketing from a chaos and complexity point of view is provided. Work in this field is rather sparse and has been spread over a period of about fifteen years. Firstly, the business environment will be provided in terms of complexity and turbulence, then a brief overview of chaos and complexity theories is provided and then the role of marketing in complex and turbulent environments from a chaos and complexity perspective is explained. Finally, the marketing mix components are examined as the basis for the marketing mix model that is presented in the next section.

\section{Business Environment}

The business environment is comprised of a set of relationships between agents or stakeholders in the environment - relationships that are changed by individual decisions taken (Lewontine, in Wheatley, 1996:20). These interactions continuously 'co-create' an environment that is changing faster than ever before (Achrol, 1991:78; Kotter, 1996:1; Glass, 1996:99; Loewen, 1997:11 and Conner, 1998:vi), with such change occurring in two major dimensions, complexity and turbulence (Dess \& Beard, in Robbins, 1990:218 and Huber, in Achrol, 1991:78).

The first component of environmental change, complexity is defined as a measure of heterogeneity or diversity in many environmental sub-factors such as customers, suppliers, socio-politics or technology (Lane \& Maxfield, 1996:217; Chae \& Hill, 1997:8 and Chakravarthy, 1997:69). As complexity increases, the ability to understand and use information to plan and predict becomes more difficult 
(Black \& Farias, 2000:103). As systems increase in complexity over time (Farrell, 1998:58), the increasing complexity leads to more change (Conner, 1998:115). As the system becomes more complex, making sense of it and predicting its behaviour becomes more difficult (Black \& Farias, 2000:102) and adapting to the changing environment becomes more problematic (Lane \& Maxfield, 1996:230 and Merry, 1999:270).

The second component of environmental change, turbulence, is defined as dynamism in the environment, involving rapid, unexpected change in the environmental sub-dimensions (Conner, 1998:109 and Vorhies, 1998:5). A stable environment changes little but, when it does, the change is predictable. In turbulent environments there are many unexpected changes. Turbulence is the natural state of the world (Benton \& Lloyd, 1992:111 and Mintzberg, 1994:7). It is caused by changes in, and interaction between, the various environmental factors especially because of advances in technology and the confluence of the computer, telecommunications and media industries (Samli, 1993:2 and lansiti, 1995:37). The result of this growth in environmental turbulence has been the reduction of orderly competition, an increasing need for information, innovation, and quicker cycles of development, and more difficulty in predicting customer, product and service requirements (Achrol, 1991:81; Pine, Victor \& Boynton, 1993:118; Haleblian \& Finkelstein, 1993:847 and Chakravarthy, 1997:69). Thus, decision windows are shorter, risk of obsolescence is greater, long-term control becomes impossible and managers have to learn new ways to operate in turbulent environments (Davis, Morris \& Allen, 1991:45). The net result of these changes is an environment that Lynch (1995:46) refers to as "chaotic, fragmented and unpredictable, and complex and turbulent." Although this seems negative, Mavondo (1999:246) has shown that destabilisation in the environment leads to heterogeneity in the business environment, thereby avoiding 'me too' strategies and encouraging differentiation.

Since complex and turbulent environments can be desirable, but since many businesses are uncertain about how to cope with such situations, it makes sense to identify ways to handle such environments. Many believe that identifying a causative link between environmental variables and management action is not possible because of the complexity of variables and the chaotic nature of environments (Winsor, 1995:181). However, recent research has stressed the inter-relationship between an organisation and its environment (Polonsky, Suchard \& Scott, 1999:52). Organisations co-exist and co-evolve with their environments and therefore are able to influence the environment to a greater extent than previously thought (Brooks \& Weatherston, 1997:13). Organisations shape their environments by influencing their industries or collaborating with each other, thereby gaining some control over some part of their environments. The environment is thus not completely determined by external forces, but can also be influenced by the organisation (Anderson, Hakansson \& Johanson, 1994, in Ford, 1997:229).

If business environments are increasingly complex and turbulent, are they not then complex adaptive systems (CASs)? Many authors clearly see environments as CASs (Tedesco, 1998:3; Peters, 1999:6; Prendergast \& Berthon, 2000:226; Holbrook, 2003:39 and Wollin \& Perry, 2004:569). Others highlight the presence of complexity constructs in business environments, such as:

- Co-determination or co-evolution taking place between firms and their environments (Achrol, 1991:78 and Polonsky, Suchard \& Scott, 1999:42).

- Self-organisation and emergence occurring through a loose coupling of participants in the environment (Peters, 1999:203).

- Environmental changes starting small and developing slowly and unpredictably, which is indicative of sensitive dependence on initial conditions (Tedesco Analytics, 2001:3).

- Business environments exhibiting non-linearity (Black \& Farias, 2000:101 and Tedesco Analytics, 2001:3).

Furthermore, Black and Farias (2000:104) have explained how actions taken to reduce uncertainty can lead to non-linearity and unpredictability. When firms make changes in a market they create 'ripples' that affect the whole market, forcing other firms to try to improve their strategic 'fit' to the shifting market. In other words, the marketplace is in a continuous state of disequilibrium and the 
more participants there are in a marketplace, the more ripples there will be, leading to further disequilibrium and more complexity. Since environments do appear to be CASs, a complexity or chaos perspective should be used to understand their dynamics and behaviour and to guide strategy development (Tedesco, 1998:3; Prendergast \& Berthon, 2000:224 and Tedesco Analytics, 2001:3). In fact, Größler et al. (2006:273) imply that greater internal complexity is needed to cope with growing external, or environmental, complexity.

\section{Complexity/Chaos Theory}

A collection of theories makes up the body of knowledge known as complexity and chaos theory (Burnes, 2005:74). The underlying idea "is that all things tend to self organise into systems" (Kelly \& Allison, 1999:5). These systems develop patterns that are created when a number of simple rules are applied over many iterations. Small differences at the start of the process can eventually result in large differences in the system's performance. Many interactions in a system can produce unexpected patterns or behaviours (Goldberg \& Markoczy, 1998:1) because stimulating one part of the system can have unexpected effects in other, unanticipated, parts of the system. Such unexpectedness is because of the nature of non-linear feedback networks (Stacey, 1996:67), the interconnected and interdependent nature of complex systems (Bar-Yam, 2000:2) and the fact that the system's parts interact and adapt to each other (Meade \& Rabelo, 2004:669). Complex behaviour is orderly, yet full of surprises. In other words, despite apparent uncontrollability, the system is not totally chaotic. The rules that generate this behaviour are part of the system, are not enforced by a single 'manager", and cannot be predicted from examining any single part of the system. Although the behaviour of complex adaptive systems cannot be predicted, it can be influenced by encouraging mutually beneficial relationships between members of the system (Baskin, 1998:16).

Several chaos and complexity concepts have relevance to business. The central concept is selforganisation, the process of a pattern of order emerging from a set of simple rules in an interconnected network. The process is not controlled through conscious awareness by an outside 'manager', but spontaneously self-organises from the bottom up through the inter-relationships of the system's parts (Holbrook, 2003:18). As a result, individual managers cannot predict and plan longerterm outcomes (Wilkinson \& Young, 1998:16 and Kelly \& Allison, 1999:94), but by fine-tuning the simple rules that determine the system, it can be moved between stability and chaos (Lewin, 1993:11). This continuous self-organisation allows and encourages a variety of creative and innovative responses to emerge from changing environments (Dolan et al., 2003:32).

This emergence is the second important concept of complexity theory. It happens when the system's parameters change, leading to a movement towards disorder - important because too much order causes the system to become ossified (Carlisle \& McMillan, 2006:5). The implication is that, to cope with change, the system should be kept at the edge-of-chaos, where innovation happens (Burnes, 2004:315) and which enables the system to reorganise itself into new patterns of relationships and from these new patterns, new actions emerge, resulting in new order 'for free' (Holbrook, 2003:18). Examples of these actions include new strategies (Conner, 1998:68), marketing tactics for specific prospects (Crosby, in Forrest \& Mizerski, 1996:58), self-directed teams (Gault \& Jaccaci, 1996:35) and strategic alliances (Wilkinson \& Young, 1998:7).

The third important concept is feedback. Negative feedback dampens changes, pushing the system back to its original state and producing regular, predictable behaviour - stability (Stacey, 1995:482; Thietart \& Forgues, 1995:20 and Glass, 1996:102). Positive feedback amplifies many small changes (McGlone \& Ramsey, 1998:249), pushing the system away from equilibrium at an escalating rate (Oliver \& Roos, 2000:124), leading to explosive instability, i.e. a turbulent market (Doherty \& Delener, $2001: 67)$. Together, positive and negative feedback act as countervailing forces, pushing the system towards instability and at the same time damping changes, thereby balancing at the 'edge-of-chaos' (Thietart \& Forgues, 1995:28 and Wollin \& Perry, 2004:563), the best position for a company in a turbulent market (Doherty \& Delener, 2001:72). Positive feedback enables a firm with an early small advantage to enjoy exponential growth until the advantage becomes 'locked in', and becomes an industry standard, as happened with VHS video recorders and Microsoft Windows (Holbrook, 2003:39). Positive feedback has been shown in customer defections (Rasmussen \& Mosekilde, 1988), product development (Millier, 1999:66), mass customisation (Saisse \& Wilding, 1997:1) and advertising (Glass, 1996:103). 
The fourth important concept is sensitive dependence on initial conditions (Phillips \& Kim, 1996:259 and Briggs \& Peat, 1999:33). In a stable system, small changes have small effects, but in a CAS, small changes can grow exponentially with each iteration, until no prediction accuracy is possible (Diamond, 1993:12; Doherty \& Delener, 2001:74 and Holbrook, 2003:11), as an infinite amount of precise data is needed for accurate long-term predictions (Mix, 1993:444). However, the concept can be used to suggest ways to cope in turbulent environments. Using small nudges to guide an event, rather than dramatic actions to control it are suggested (Wheatley, 1996:23). Traditionally, a small change would be ignored in business. However, the right kind of 'nudge' at the correct time (the initial condition) can lead, through positive feedback, to major changes (Nilson, 1995:40). Being a 'first mover' is essential because sensitive dependence on initial conditions and positive feedback create a 'flywheel affect' that reinforces early success, providing a significant advantage over the long-term (Hamel \& Prahalad, 1994:177 and Koch, 2000:193). To be a successful first mover, a company must recognise the patterns and spot the environmental clues that indicate which small changes to 'nudge' (Ball \& Asbury, 1989:97 and Morrison \& Quella, 1999:23) and when to nudge them, the 'tipping point' (Gladwell, 2000:139).

Attractors, the fifth important complexity concept, reflect the underlying order or structure in a CAS (Thietart \& Forgues, 1995:28). Within the apparent randomness of a chaos system, predictable patterns can be found. The edge-of-chaos attractor, known as a 'strange attractor', reflects the area where maximum creativity and innovation happens (Burnes, 2004:315 and Carlisle \& McMillan, 2006:5). This transition between order and chaos is the point at which sensitive dependence on initial conditions causes small inputs to cause big changes. A unique feature of the strange attractor is that it has a coherent pattern and always stays within certain boundaries (Holbrook, 2003:14). Behaviour is never identical within these boundaries, but is broadly predictable. Exactly where the system will go next cannot be predicted, but it will not go outside certain limits (Doherty \& Delener, 2001:69 and Wollin \& Perry, 2004:569), thereby permitting change, while maintaining some order. This bounded stability allows the system to continually adapt, approaching the edge of chaos, but pulling it back from plunging into disorder, chaos and failure (Frederick, 1998:367). Strange attractors in business could include corporate vision and values (Frederick, 1998:375), industry standards (Black \& Farias, 2000:108) and customer relationship management (Kurtyka, 2000:8). Strange attractors have also been shown mathematically or via simulations in customer behaviour (Herbig, 1990:69), inventory levels (Rasmussen \& Mosekilde, 1988), and advertising (Feichtinger, Hommes \& Milik, 1994:109).

\section{Marketing}

Marketing success in a turbulent environment requires an approach that is different to that recommended by traditional strategic marketing theory, which is insufficient to guide marketers in markets in varying states of change and turbulence. For example, the product life cycle approach can be misleading if other environmental factors are not considered concurrently, and the marketing warfare approach focuses only on the competitive environment, not taking adequate account of developments in the other environmental variables. Thus, these strategic approaches are unlikely to enable companies to develop and maintain defendable, competitive positions over the long-term. Furthermore, they are not consistent with the current strategic approaches of collaboration and networking (Mason, 2004:174). This criticism of the traditional approach to marketing strategy is supported by other authors who believe that sequential strategic marketing planning does not suit a changing environment because it is too slow and unresponsive for a fast changing marketplace, nor can it keep up with customers' requirements or with aggressive competitors (Nilson, 1995:27 and Pine, in Heilbrunn, 1995:8). In addition, traditional market research and traditional marketing mix models are too simplistic to understand complex marketing situations, as such models assume linear relationships between mix variables and the resultant outcomes (McGlone \& Ramsey, 1998:248 and Tedesco, 1998:5). Since the simplistic approaches recommended by traditional theories can be dangerous, marketers should consider the overall environmental position when designing their strategies and adopt non-traditional marketing methodologies (Wollin \& Perry, 2004:568).

In current complex and turbulent environments, speed in recognising opportunities and developing new products, as well as reducing the time to market is essential (Manning, 1991:74; Morris, 1996:13 and Größler et al., 2006:262). Since decisions and actions have to be taken without total clarity of information, planning should concentrate on 'how to do it' and keep the 'what to do' options open as late as possible (Nilson, 1995:70). For marketing to be effective, it must be proactive, not reactive. It must create events, and not merely rely on market research, since competitors can too easily copy 
the reactive following of customer requests. In other words, marketing innovation is essential. Richardson (1996:1) supports this view by maintaining that:

"traditional marketing is an inadequate response to the marketing opportunities emerging in a modern economy and is inappropriate for the complex social, economic, cultural and political climate of the late twentieth century and beyond."

Nilson (1995:107) maintains that, as the environment, product and customers become more complex, it is essential for a firm to focus its scarce resources on those key activities that will give the best result. He maintains that there are two approaches to using marketing tactics effectively in chaotic environments: stabilising or destabilising approaches.

McGlone and Ramsey (1998:251) agree that some marketing activities have a stabilising effect on the company by encouraging the system to behave within boundaries, while other marketing activities have a destabilising effect by causing unanticipated consequences that break the system boundaries. This is typical of a 'chaos system', but, according to Nilson (1995:173), "a system that is totally out of control is really just that: uncontrollable." Thus, a dynamic chaos market system is preferred. In other words, a system operating at the edge of chaos is preferred because stabilising and destabilising activities can be used to balance the system between uncontrollability and stagnation. Thomas (in D'Aveni, 1999:129) found that companies following a stabilising approach produced better returns in a more stable environment, but that there was little difference between better and poorer performers. However, when turbulence increased, companies following a stabilising strategy produced worse results and the gap between successful and less successful company performance increased. This implies that destabilising tactics used in more turbulent markets should lead to greater success than when stabilising tactics are used in such markets. Mohr (2001:45) maintains that companies in changing environments must not allow their core competencies to become core rigidities, creating lock-in to old or obsolete technologies or products and hindering new product development. This could happen if a firm concentrates on stabilising tactics that tend to keep the firm and its environment in equilibrium. To avoid this she suggests 'creative destruction', which involves continuously innovating in order to make the firm's own products obsolete and to replace them with the firm's own developments. Continuous leadership in a market is not possible without this creative destruction, which is a form of continuous destabilisation.

From a chaos and complexity perspective, stabilising can be seen as reducing the rate of change by encouraging negative feedback, or damping, which brings the system back towards its equilibrium point, or to within its attractor boundaries (Nilson, 1995:35 and Hibbert \& Wilkinson, 1994:229). In a more marketing oriented sense, Nilson (1995:47) says that destabilising means the disrupting of a 'stable' environment, or reinforcing or increasing change in a particular direction. It also implies increasing the rate of change, setting off events to change the marketing system or unsettling the established market, often through guerrilla tactics. Another way of defining destabilisation is to see it as encouraging positive feedback, also known as 'the nudge' effect, thereby moving the system away from the status quo. Thus, destabilisation can be either small, seemingly insignificant actions that influence the environment, or large dramatic actions that cause dramatic shifts in the environment. However, it must be remembered that the outcome is uncertain, but Garcia (2004:4) shows that such risk-taking leads to greater marketing competencies and innovation in turbulent environments, especially when related to product development. Nilson (1995:50) ranks marketing tactics in terms of stabilising or destabilising as shown in Table 1 below: 
Table 1: Marketing tactics as stabilising or destabilising

\begin{tabular}{|l|} 
Most destabilising \\
Totally new products \\
Price change \\
Product innovation (new product development) \\
Sales promotion \\
Product enhancement (old product development) \\
PR and other forms of non-advertising \\
communication \\
Advertising \\
Personal selling \\
Own distribution system \\
Most stabilising \\
\hline
\end{tabular}

\section{The Marketing Mix}

The classic 4Ps of marketing have been questioned as inadequate (Van Waterschoot \& Van den Bulte, 1992:91), and developed further into the 7Ps of Booms and Bitner (in Zeithaml \& Bitner, 2003:24) and of Christopher et al. (in Palmer, 1994:32). However, the 4Ps is still the most common model of the marketing mix (e.g. Kotler \& Keller, 2006:19), and it has been consistently used in chaos and complexity articles on marketing. Therefore the standard 4P model was used for this paper.

In traditional marketing, product, price and place are essentially fixed over the short term, with only promotion being considered variable. In a turbulent market, though, all of the marketing mix variables should be considered as continuously variable (Morris, 1996:13). Therefore, understanding each of the marketing mix elements from a complexity perspective is important.

Product is usually the first element of the mix considered, with new product development one of the most important destabilising tactics. Modis (1998) maintains that product mutations grow at the start and at the end of the product life cycle and the more there are, the better the chance that some will survive and become established. Therefore, destabilisation and chaos should be encouraged as a product development strategy. Nilson (1995:88) maintains that introducing a totally new product is one way of introducing chaos into a market, i.e. destabilising an existing market. For such an approach to be successful, a longer-term view is necessary, but the company must also be prepared to act innovatively in the short term to take advantage of unanticipated and unpredictable opportunities. This means short lead times, fast feedback loops and flexible development processes (Nilson, 1995:108). This involves product development systems that can make late design changes to better meet customers needs and that can avoid design changes entirely because design specifications and commitments can be made very late in the process (Golden, Johnson \& Smith, 1995:17 and Thomke \& Reinertsen, 1998:14). Numerous trials, test markets and experiments are required, producing many new lines, improvements and repositioning efforts (Morris, 1996:13). This concept of short-term adaptability and flexibility becomes even more important when the effect of information intensity is considered. Information intensive firms, such as high technology firms, have shorter product life cycles and less time to launch and establish new products successfully (Glazer, 1991:7). Although speed and flexibility is important, it must not be at the expense of unique attributes, value for money, superiority in meeting customers' needs, and excellent relative product quality, which can prevent, or slow down, entry of competitors to the market, can encourage early adoption of the product and can justify higher prices, thereby reducing the pay back period in shortened product life cycles (Cooper, 1994:2 and Benkenstein \& Bloch, 1994:4).

Regarding the product range in a turbulent market, new lines, additions to lines and product extensions are required (Morris, 1996:13). Millier (1999: 66) stresses the importance of encouraging chaos and destabilisation during new product development in order for proliferations to take place. The 'chaos' enables the product to develop as the customer uses it, with the 'perfect' product emerging from the inter-relationships between product and customer use, rather than from rigid product planning. This implies that in turbulent markets an increase in the range can be expected. Some authors propose range reductions in turbulent markets, but they all see equilibrium as the desired state (Benkenstein \& Bloch, 1994:5; Nilson, 1995:120 and Schiller, Burns \& Miller, 1996:96). 
Rapidly growing product ranges are facilitated by the growth of flexible manufacturing, which has enabled companies to achieve mass marketing and customisation. This means that the specific local needs of customers can be met through enlarged ranges without losing economies of scale (Nilson, 1995:114). Such customisation supports range extension by enabling consumers to 'create' their own product, rather than accepting the product as presented by the supplier, reflecting the consumers' choices of what they really want. The product then becomes 'their product', creating ownership and tying them to that supplier. While range increase is important in complex and turbulent markets, range reduction, or culling of products from the range, is equally important, because slow sellers drain resources from the marketing system (Nilson, 1995:105). Culling the company's own products in order to keep ahead of competitors is important, disrupting the environment for the competitors (Grulke \& Silber, 2000:97). In addition, many 'high tech' products do not reach maturity because of the short product life cycle, and so high tech firms have to continuously bring in innovations that make their own products obsolete (Mohr, 2001:45). Range enhancement, or old product development, is important, but mainly as a stabilising activity (Nilson, 1995:109).

Regardless of the type of product development, speed of execution is critical in order to respond rapidly to evolving technical and market changes in complex and turbulent markets. The speed of new product development must be faster than the changes in the environment, as changes in turbulent markets often happen quicker than the typical product development time scale (Samli, 1993:111). In a turbulent environment, change happens so quickly and unexpectedly that, by the time an imitator has copied the strategy, that original strategy has been changed and made obsolete by its originator. In other words, innovation, as opposed to imitation, is essential in a turbulent environment with short product life cycles (Morris, 1996:13).

Although many of the product management activities are destabilising, the brand is an important stabilising factor. In a market facing rapid change and turbulence, a strong brand name can be very important because, as the time available to communicate with the customer in shortened life cycles decreases, the brand is able to rapidly communicate the values for which it stands (Nilson, 1995:143). Thus, branding is a stabilising activity, necessary in a turbulent environment to support the application of destabilising activities.

Price is a marketing tactic that can be used both as a stabilising and a destabilising tactic. Status quo pricing strategies, for example, attempt to maintain the market pricing system, that is, supply and demand, at equilibrium, while dramatic price changes can disturb the system and change the nature of market demand. Applying complexity/chaos theory, marketers can use the 'nudge' effect, or sensitive dependence on initial conditions, to encourage a market to change in a desired direction (Nilson, 1995:40). If a company cuts price to increase sales, competitors follow suit and a price war results. If this receives a positive response from the market (a positive feedback loop) it may result in a total restructuring of the market, a result that was not anticipated. However, a company understanding the non-linear nature of these relationships should be prepared for the unexpected and should be able to take advantage of the restructuring better than its competitors, thereby building a new competitive advantage. The use of aggressive pricing strategies is likely to destabilise the marketing system (Nilson, 1995:122). This is particularly true if the business environment is price focussed. In a price-oriented market, aggressive price promotions can win short-term sales benefits. However, if a company wants to introduce an 'everyday-low-price' policy in such a market, it will probably lose sales unless it quickly introduces stabilising dimensions in the market. As a corollary to this, Pitt, Berthon and Morris (1997:6) maintain that increasing competitor hostility leads to more price-orientated competition. This is more than mere price-cutting and includes greater creativity in the use of price variables, such as price differentials according to market segments, time of consumption, payment schemes and discount structures. Short-term tactics, such as rebates, coupons, cents-off deals and price promotions create more innovative, flexible and proactive pricing strategies. In addition to aggressive pricing, successful companies in turbulent markets price differently from other companies. Pricing approaches are more complex, more customized, have a superior value proposition, prices are set in different ways and are often very low, or even free and rely on generating profits from upgrades, add-ons, service, installations and complementary products (Pitt, Berthon \& Morris, 1997:7; Roberts, 2000:7; Kumar, Scheer \& Kotler, 2000:133 and Mohr, 2001:26). A further reason for the importance of pricing as a destabilising market tactic is that it is very visible. Prices send clear signals to the market about product value and company objectives, and frequent price changes indicate to the market that this is an innovative firm. Thus, pricing tactics can 
also act as a communication device to the market, instigating word-of-mouth advertising (Pitt, Berthon \& Morris, 1997:2).

Place, or distribution, is traditionally one of the most conservatively handled marketing tactics, with minimal change taking place. Distribution and availability are two of the main stabilising dimensions of the marketing mix. This is because, by controlling the link between supplier and customer, the supplier reduces the customer's ability to change suppliers, thereby making the market more stable. This also applies similarly to backward integration by retailers and to forward integration by manufacturers, which reduce the uncertainty of whether the retailer will stock the manufacturer's product or not. This stabilises the environment (Nilson; 1995:47). A distribution channel is a non-linear system that can be stable, periodically oscillating, or chaotic (Priesmeyer, 1992:79). The more members there are in the channel, the more complex the system becomes. Coping with this complexity can be done better if the channel members are able to identify and understand the attractor pattern of the system. Managing the whole system (i.e. the supply chain) according to the attractor pattern can enable efficiencies to be achieved. If each element of the chain tries to optimise its own performance, there is a likelihood that minor ordering differences or disturbances can be amplified up the chain, resulting in large, unpredictable disturbances at, for example, the manufacturer level (Forrester, in Stacey, 1996:207). The solution is to treat the whole supply chain as a single system, aiming for optimisation of the system rather than the individual elements. This is supported by Wilding (1998) who found that some stabilising actions could in fact increase other sources of uncertainty. He concludes that introducing any change to a supply chain system should be done with extreme care. Simulation and modelling of supply chains is also being used to better understand their dynamics and complexity and to help with decision-making (Turner \& Williams, 2004:456). Considerable emphasis is placed on stabilizing dimensions such as partnerships and strategic alliances (Glazer, 1991:12 and Mohr, 2001:286), buffer inventories (Hibbert \& Wilkinson, 1994:230 and Phillips \& Kim, 1996:258) and planned inventory replenishment (Johnston and Betts, 1996:14). However, there is agreement that destabilising actions can be necessary, especially when a company does not have ready access to distribution channels (Nilson, 1995:82) or when a radical innovation is implemented (Kumar, Scheer \& Kotler, 2000:134). Suggested actions that have been adopted include the use of short-term forecasts and prediction of patterns (Wilding, 1998:611), the reduction of intermediaries and the increase in direct distribution (Nilson, 1995:82; Hooley \& Beracs, 1997:162 and Roberts, 2000:39), the use of reaction, as opposed to planning, for inventory replenishment (Johnston \& Betts, 1996:14) and the use of agent-based models to manage inventory (Robertson, 2004:76).

Although promotion or marketing communications are mostly stabilising elements, they can be destabilising. As communications become faster and consumers change in terms of education, sophistication and different cultures, uncertainty increases, so awareness of, and monitoring for, uncontrolled behaviour in the system becomes essential. However, it should be noted that, in terms of complexity/chaos theory, communications is unlikely to be able to achieve major, predictable disruptions in the marketplace, e.g. changing consumer attitudes and behaviours. It can, however, encourage, or 'nudge', an already changing attitude or behaviour. Thus, a marketer can, through communications, speed up a change that has already started (Nilson, 1995:134). Understanding the attractor prevalent in a market enables the marketer to identify the appropriate marketing tactics. More aggressive promotional tactics in a turbulent market allow the alert marketer to take advantage of the turbulence to influence, or nudge, the trajectory of the attractor in order to increase market share, sales or profitability (Priesmeyer, 1992:76).

Feichtinger, Hommes and Milik (1994:109) suggest that a firm in a more stable market would benefit from a continuous, conservative and defensive advertising strategy, typically image or institutional advertising, while a firm in a more turbulent market would benefit from a more aggressive, pulsed advertising campaign, typically product advertising (pioneering or competitive advertising).This indicates that advertising can be both stabilising and destabilising in its effects. Herbig (1990:72) found that emphasis on publicity and advertising would be stabilising and Nilson (1995:83) maintains that a large company can use advertising to minimise volatility, because the high costs of advertising can act as a barrier to entry, reducing competitive complexity and turbulence, and by building brand loyalty, which itself is a stabilising factor. Advertising can be used as a destabilizing tactic by hijacking another brand's reputation via comparative advertising (Nilson, 1995:92), by using a new, innovative, controversial or shocking campaign (Dru, 1996:54), by increasing complexity of logo design (Foo, 
2003:16) or by using a highly creative approach to change the perceptions about a market, i.e. 'changing the rules of the game' (Nilson, 1995:92).

Personal selling and relationship building is a stabilising factor. Through sound salesperson-buyer relationships, customer can be encouraged to remain loyal to the supplier (Nilson, 1995:159). A company that can establish a learning relationship with its customers should retain them because the company learns more about their needs, while the customer would have so much time and effort invested that it would not be worthwhile switching to a competitor (Pitt, 1995:19). Personal selling, because of its personal dialogue, can create a dominating position in the mind of the customer. The sales force has a key role as a feedback loop between customer and company, and even though it is a stabilizing function, in a turbulent environment fast communication is required between the sales force and marketing management (Nilson, 1995:160). This requires the sales force to be decentralised and empowered to take decisions (Cespedes, 1996:33), and to have strong marketing knowledge to achieve this, especially in mature and stable markets (De Vasconcellos, 1991:268). This highlights the importance of personal selling as a stabilisation function in stable and simple environments.

Much of what has been said about personal selling may also be true of public relations (PR), as PR also emphasises relationship building and can thus be seen as stabilising (Herbig, 1990:75). Nilson (1995:157) agrees that it can be a very effective method of disseminating information and building loyalty to a company. However, in complexity/chaos terms, a relatively small and inexpensive PR activity (a 'nudge') can lead to significant outcomes because of the multiplier effect. However, like all activities based on sensitive dependence on initial conditions, the result is unpredictable. Although the instigator of the action hopes for a positive response, they have no control over the dissemination of the information, nor over the way the message is presented.

Sales promotion activities, especially when linked to price promotions, create instability in a market and so are destabilising (Nilson, 1995:122). The more unusual the promotion the greater the likelihood of an outcome different to what was expected. However, if the sales promotion follows a theme (such as competitions, cross promotions, etc.) it can stabilise the system. Promotions that build relationships have the same stabilising effects as advertising. Direct mail, or direct marketing, via the building of a relationship with customers through personalised communications with the help of a database, can also be stabilising. Research into the non-linear dynamics of sales patterns at two petrol retailers with significantly different environments supported this (Priesmeyer, 1992:75). The retailer with a less turbulent environment was not influenced significantly by price cuts or promotional activities, whereas the retailer with a highly turbulent environment had more opportunities for influencing demand through promotional tactics. In fact, minor promotional changes resulted in major increases in sales and profitability. This study showed that aggressive sales promotional tactics in a turbulent market could enable a marketer to influence the trajectory of the attractor to increase sales, market share or profit.

A final promotional method is word-of-mouth. Herbig (1990:75) found a relationship between word-ofmouth advertising and chaos, resulting in word-of-mouth being seen as destabilising. Word-of-mouth advertising involves activities that are likely to encourage consumers to talk about a product or a company, to their friends and neighbours, setting in motion a chain of communication that could branch out through a whole community. It involves using reference groups and opinion leaders to spread information and knowledge about the product or company. Promotional activities that encourage talking about the company or product, i.e. positive word-of-mouth, should be used. Each activity, small and relatively unimportant in itself, could escalate through word-of-mouth to create strong and positive brand images and beliefs. It can be seen that the principles of sensitive dependence on initial conditions or the nudge effect are at work here. In explaining word-of-mouth, Nilson (1995:159) stresses that it has a very strong non-linear effect and is impossible to control. However, since the principle of sensitive dependence on initial conditions is at work, a small investment in encouraging customers to talk about a product or service can produce a significant effect. It is more relevant in turbulent, high technology markets because high technology products are not able to build brand image over years or decades because they have short product life cycles (Smith et al., 1999:646 and Mohr, 2001:285). Therefore, the quick spread of word-of-mouth is important. This is supported by Mohr (2001:343) who suggests the use of viral marketing to encourage the rapid spread of word-of-mouth. Horovitz (2002:3) maintains that the young 'generation $Y^{\prime}$ market cannot be reached through traditional promotions and suggests that word-of-mouth or 'buzz' type promotions is being used by successful marketers in this rapidly changing and turbulent 
segment. Clearly word-of-mouth is an important promotional tactic, but it does not happen by itself - it must be organised systematically by identifying influential individuals, winning their support and providing information to enable them to spread the word (Peters, 1987:241 and Heckman; 1999:2). Word-of-mouth thus appears to be a very effective tactic for use in an environment that is at the edge of chaos, as it is grounded in one of the main characteristics of chaos theory, namely sensitive dependence on initial conditions.

\section{THE MODEL OF MARKETING MIX TACTICS}

Summarising the findings of the above literature review and analysis, a model was developed of the tactics that chaos and complexity theories suggest would be adopted by a successful company in a complex and turbulent business environment. The model is presented in Table 2 according to the same headings and sub-headings used in the discussion above.

Table 2: Marketing Mix Model - for success in a complex/turbulent environment

\begin{tabular}{|c|c|}
\hline PRODUCT & \\
\hline NPD planning & Short-term planning. Involve customers in process \\
\hline Range change & Increasing ranges due to continuous new products, destabilising markets \\
\hline $\begin{array}{l}\text { Culling of } \\
\text { products }\end{array}$ & Slow sellers/losing products culled to avoid drain on company resources. \\
\hline $\begin{array}{l}\text { Product } \\
\text { innovation }\end{array}$ & $\begin{array}{l}\text { Use to destabilise market. Lots of trials leading to stream of new products. } \\
\text { Make own products obsolete to avoid rigid competencies. }\end{array}$ \\
\hline $\begin{array}{l}\text { Product } \\
\text { enhancement }\end{array}$ & $\begin{array}{l}\text { Less important - improve current products to offset cost \& difficulty of launching } \\
\text { new products }\end{array}$ \\
\hline $\begin{array}{l}\text { Product } \\
\text { customisation }\end{array}$ & $\begin{array}{l}\text { Individual, local needs met through enlarged ranges of customised products - } \\
\text { unique, personalised, in many permutations. All aspects of product } \\
\text { customised. }\end{array}$ \\
\hline $\begin{array}{l}\text { Speed of product } \\
\text { development }\end{array}$ & $\begin{array}{l}\text { Very fast to bring product to market before competitors \& before needs } \\
\text { change. Short lead times, fast feedback loops because of short PLC. Launch } \\
\text { NP \& respond to market changes quickly. }\end{array}$ \\
\hline $\begin{array}{l}\text { Product design / } \\
\text { flexibility }\end{array}$ & $\begin{array}{l}\text { Flexible to handle environment shifts \& late design changes. Able to set } \\
\text { design specs late in process. }\end{array}$ \\
\hline Branding & $\begin{array}{l}\text { Quickly conveys image, long-term stability in rapidly changing, destabilised } \\
\text { market. }\end{array}$ \\
\hline Importance & $\begin{array}{l}\text { Critical - often basis of destabilisation. Rest of mix determined by product } \\
\text { tactics. }\end{array}$ \\
\hline PRICE & \\
\hline $\begin{array}{l}\text { Aggressive } \\
\text { pricing }\end{array}$ & Price promotions especially in hostile competition \& price focussed markets. \\
\hline Price leadership & Lead market in initiating price changes, price-cutting. Different pricing policies. \\
\hline $\begin{array}{l}\text { Innovation in } \\
\text { pricing }\end{array}$ & $\begin{array}{l}\text { Novel, unexpected pricing, including price differentials, payment schemes \& } \\
\text { discount structures. }\end{array}$ \\
\hline Price setting & $\begin{array}{l}\text { Complex/sophisticated/flexible methods to customise prices \& adapt to } \\
\text { changes. Integrate with other elements of marketing mix }\end{array}$ \\
\hline Price premium & $\begin{array}{l}\text { Obtained via customer's inability to assess costs. Quality/value as negotiation } \\
\text { base }\end{array}$ \\
\hline Importance & Important: visible, communicates with market, stimulates w-o-m, destabilizes. \\
\hline PLACE & \\
\hline $\begin{array}{l}\text { Changes in the } \\
\text { channel }\end{array}$ & $\begin{array}{l}\text { Treat supply chain as single system. If change needed, should be done } \\
\text { carefully. }\end{array}$ \\
\hline Intermediaries & Reduction of use intermediaries. Deal more with end users. \\
\hline $\begin{array}{l}\text { Partnerships/ } \\
\text { alliances }\end{array}$ & $\begin{array}{l}\text { Used to balance destabilization in other elements. Blurring of boundaries \& } \\
\text { roles. Staff work on customer/supplier site. Shared info \& systems. . }\end{array}$ \\
\hline $\begin{array}{l}\text { Physical } \\
\text { distribution }\end{array}$ & Quick delivery to reduce need for inventory - often same-day delivery. \\
\hline Stock levels & $\begin{array}{l}\text { Inventory load shared throughout supply chain. Quick response \& integrated } \\
\text { computer systems }\end{array}$ \\
\hline
\end{tabular}




\begin{tabular}{|l|l|}
\hline $\begin{array}{l}\text { Stock } \\
\text { replenishment }\end{array}$ & $\begin{array}{l}\text { Short-term, reactive management - inventory based on end user, rather than } \\
\text { intermediate, customer demand. }\end{array}$ \\
\hline Importance & $\begin{array}{l}\text { Important but a 'given'. Total channel system copes with environmental } \\
\text { turbulence. }\end{array}$ \\
\hline PROMOTION & $\begin{array}{l}\text { Pulsed, pioneering, competitive or product oriented. Comparative ads disrupt } \\
\text { consumers' beliefs re competitors. Creative campaigns create controversy, } \\
\text { shift perceptions \& change 'rules of the game.' }\end{array}$ \\
\hline Pedia advertising & Although needed, is seen as less important for destabilising in turbulent market \\
\hline Public relations & $\begin{array}{l}\text { Less important, but small PR activities can nudge system towards } \\
\text { destabilisation. }\end{array}$ \\
\hline Sales promotions & $\begin{array}{l}\text { If used with price, can be effective/destabilizing. Minor, but unusual } \\
\text { promotions/ changes lead to major impacts. More effective than adverts in } \\
\text { turbulent markets. }\end{array}$ \\
\hline Word of mouth & $\begin{array}{l}\text { Very important - 'influence-the-influencer' promos. Spread info re new, } \\
\text { amazing aspects of product. Use multiplier channels like Internet, discussion } \\
\text { groups. }\end{array}$ \\
\hline $\begin{array}{l}\text { Aggressive use } \\
\text { of promotions }\end{array}$ & $\begin{array}{l}\text { Aggressive use enables trends to be nudged \& advantage to be taken of } \\
\text { turbulence }\end{array}$ \\
\hline Speed of change & $\begin{array}{l}\text { To be unusual \& surprising, campaigns must be short-term, \& changed } \\
\text { frequently. }\end{array}$ \\
\hline Importance & Important to manage via nudge effect, but less effective for major changes. \\
\hline
\end{tabular}

\section{IMPLICATIONS FOR MARKETERS}

This paper demonstrates that chaos and complexity theories can help to better understand the market environments and the applicable marketing tactics being experienced by companies in complex and turbulent environments, typically experienced in developing countries. It could help South African and other African marketers to adopt marketing strategies tactics that are different to those developed by more traditional international marketers, and which therefore may be more relevant to the South African and African business environments.

Viewing environments and markets through a chaos and complexity lens can enable marketers to identify opportunities sooner and more clearly than when using traditional marketing approaches. In addition, using the proposed marketing mix model would then help to quickly identify the relevant actions and tactics to be adopted for the identified opportunity.

At a micro level, it is believed that the marketing mix model may help marketers to develop superior marketing tactics more suitable for the environments in which their firms operate, and also to better understand the behaviour and dynamics of competitors in their markets, thereby increasing their chances of achieving and maintaining a competitive advantage in the market.

\section{CONCLUSIONS AND RECOMMENDATIONS FOR FURTHER RESEARCH}

Business environments in the twenty-first century are becoming increasingly complex, turbulent and unpredictable. The traditional approaches to managing marketing are becoming unsuitable for such turbulent environments. To be successful in such environments companies need to adopt a different way of managing their marketing activities. This paper, by integrating the business environment, marketing, and chaos and complexity theory, proposes a different way of identifying marketing tactics for turbulent environments, and as such has contributed to the marketing literature and the literature on business environments.

The paper proposes a model of what marketing tactics, namely, product, price, place and promotion, should be adopted for a company to increase its chances of success in a complex and turbulent business environment. However, this is still only a proposed model and therefore, further research in the field is needed. Specific research that is required could include studies investigating:

- what tactics are adopted by firms in turbulent environments

- if the tactics of successful and unsuccessful firms are different in turbulent environments 
- how the tactical model might differ in different environments, e.g. in different African countries

- Iongitudinal studies, in turbulent environments, of firms that follow the tactics proposed by the model in order to evaluate the long-term implications of the model.

- each of the marketing tactics, namely, product, price, place and promotion, in more depth.

The literature is rather slowly, and over a long period of time, building up a body of knowledge about marketing from a chaos and complexity viewpoint. This is in contrast to fields such as biology, economics, environmental ecology, and even business strategy and management, which have adopted chaos and complexity theories as important methods of studying their disciplines. This paper contributes to marketing knowledge by showing an alternative approach to examining marketing tactics, and researchers in marketing are urged to continue to advance the understanding of marketing by further use of the chaos and complexity theories.

\section{REFERENCES}

Achrol RS. 1991. Evolution of the Marketing Organization: New Forms for Turbulent Environments. Journal of Marketing, 55 October: 77-93.

Ahmed PK, Hardaker G \& Carpenter M. 1996. Integrated Flexibility - Key to Competition in a Turbulent Environment. Long Range Planning, 29(4):562- 571.

Aktouf O, Chenoufi M \& Holford WD. 2005. The False Expectations of Michael Porter's Strategic Management Framework. Problems and Perspectives in Management, 4:181-200.

Babbie E \& Mouton J. 1998. The Practice of Social Research. Cape Town: Oxford University Press.

Ball A \& Asbury S. 1989. The Winning Way. Johannesburg: Jonathon Ball.

Bar-Yam Y. 2000. Guide to Complex Systems, New England Complex Systems Institute [Online] Available from: www.necsi.org/guide [Accessed 29/6/2000].

Baskin K. 1998. Corporate DNA: Learning from life. Boston: Butterworth-Heinemann.

Benkenstein M \& Bloch B. 1994. Strategic Marketing Management in Hi-tech Industries: A stocktaking. Marketing Intelligence \& Planning, 12(1):1-6.

Benton P \& Lloyd B. 1992. Riding the whirlwind: Managing turbulence. Long Range Planning, 25(2):111-118.

Black J \& Farias G. 2000. Dynamic Strategies: Emergent Journeys. Emergence, 2(1):101-113.

Briggs J \& Peat FD. 1999. Seven Life Lessons of Chaos: Timeless Wisdom from the Science of Change. New York: Harper Collins.

Brooks I \& Weatherston J. 1997. The Business Environment: Challenges and Changes. London: Prentice Hall.

Burnes B. 2004. Kurt Lewin and complexity theories: back to the future? Journal of Change Management, 4(4):309-325.

Burnes B. 2005. Complexity theories and organizational change. International Journal of Management Reviews, 7(2):73-90.

Carlisle Y \& McMillan E. 2006. Innovation in organizations from a complex adaptive systems perspective. Innovation in organizations from a complex systems perspective, 8(1):2-9.

Cespedes FV. 1996. Beyond Teamwork: How the Wise can Synchronise. Marketing Managememt, 5(1):24-37. 
Chae M \& Hill JS. 1997. High versus low formality marketing planning in global industries: determinants and consequences. Journal of Strategic Marketing, 5:3-22.

Chakravarthy B. 1997. A New Strategy Framework for Coping with Turbulence. Sloan Management Review, Winter: 69-82.

Coffee A \& Atkinson P. 1996. Making Sense of Qualitative Data: Complementary Research Strategies. Thousand Oaks: Sage.

Conner DR. 1998. Leading at the Edge of Chaos: How to Create the Nimble Organization. New York: John Wiley.

Cooper RG. 1994. New Products: the factors that Drive Success. International Marketing Review, 11(1):1-9.

D'Aveni RA. 1999. Strategic supremacy through disruption and dominance. Sloan Management Review, 40(3):127-135.

Davis D, Morris M \& Allen J. 1991. Perceived environmental turbulence and its effect on selected entrepreneurship, marketing and organizational characteristics in industrial firms. Journal of the Academy of Marketing Science, 19(1):43-51.

De Vasconcellos JAS. 1991. Key Success Factors in Marketing Mature Products. Industrial Marketing Management, 20: 263 - 278.

Diamond AH. 1993. Chaos Science. Marketing Research, 5(4): 9-15.

Doherty N \& Delener N. 2001. Chaos Theory: Marketing and Management Implications. Journal of Marketing Theory and Practice, 9(4): 66-75.

Dolan SL, Garcia S \& Auerbach A. 2003. Understanding and Managing Chaos in Organisations. International Journal of Management, 20(1):23-35.

Dru JM. 1996. Disruption: Overturning Conventions and Shaking Up the Marketplace. New York: Wiley.

Edgar DA \& Nisbet L. 1996. A Matter of Chaos: some issues for hospitality businesses. International Journal of Contemporary Hospitality Management, 8(2):6-9.

Farrell W. 1998. How Hits Happen: Forecasting Predictability in a Chaotic Marketplace. New York: Harper Business.

Feichtinger G, Hommes CH \& Milik A. 1994. Complex dynamics in a threshold advertising model. OR Spektrum, 16:101-111.

Foo CT. 2003. Visualizing complexity in corporate identity on the Internet: an empirical investigation. Corporate Communications: An International Journal, 8(1):11-17.

Ford D. 1997. Understanding Business Markets. 3rd ed. London: The Dryden Press.

Forrest E \& Mizerski R (eds). 1996. Interactive Marketing: The Future Present. Lincolnwood: NTC Business Books.

Forsdick G. 1995. The Management of Complexity in the Oil and Chemical Industry. Master of Business Administration dissertation. Faculty of Management, University of the Witwatersrand, Johannesburg.

Frederick WC. 1998. Creatures, corporations, communities, chaos, complexity: a naturological view of the corporate social role. Business and Society, 37(4):358-376.

Gault S \& Jaccaci A. 1996. Complexity meets periodicity. The Learning Organization, 3(2):33-39. 
Garcia R. 2004. Encouraging Failure in New Product Development [online]. Paper presented at New Priorities and Challenges for Business-to-Business Marketers, 5 - 6 August, Harvard Business School, Boston [Online] Available from: www.smeal.psu.edu/isbm/seminars/boston04/Garcia.pdf [Accessed 17/9/2004].

Gilmore JH \& Pine II BJ. 1997. The Four Faces of Mass Customization. Harvard Business Review, January - February:91-101.

Gladwell M. 2000. The Tipping Point: How little things can make a big difference. London: Abacus.

Glass N. 1996. Chaos, Non-linear Systems and Day-to-day Management. European Management Journal, 14(1):98-105.

Glazer R. 1991. Marketing in an Information-Intensive Environment: Strategic Implications of Knowledge as an Asset. Journal of Marketing, 55 October:1-19.

Goldberg J \& Markoczy L. 1998. Complex Rhetoric and Simple Games [online]. Cranfield University [Online] Available from: www.Cranfield.ac.uk/public/cc/cc047/papers/complex/html /complex.htm [Accessed 2/2/1999].

Golden PA, Johnson DM \& Smith JR. 1995. Strategic orientation and marketing strategies in transition economies: a study of Russian firms. Journal of Strategic Marketing, 3:1-22.

Größler A, Grübner A \& Milling PM. 2006. Organisational adaptation processes to external complexity. International Journal of Operations \& Production Management, 26(3):254 - 281.

Grulke W \& Silber G. 2000. Ten lessons from the future. Johannesburg: @One Communications.

Haleblian J \& Finkelstein S. 1993. Top management team size, CEO dominance, and firm performance: The moderating roles of environmental turbulence and discretion. Academy of Management Journal, 36(4):844 - 863.

Hamel G \& Prahalad CK. 1994. Competing for the Future. Boston: Harvard Business School Press.

Harris L. 2005. The right stuff: what does it take to be an effective organizational leader today? Interview with Brand Pretorius. CONVERGENCE, 6(1):24-27.

Heckman J. 1999. Word-of-mouth advertising: Cheap, credible, created. Marketing News, 1 February: 2.

Heilbrunn J. 1995. AMA Marketing Encyclopaedia: Issues and Trends Shaping the Future. Chicago: American Marketing Association.

Herbig PA. 1990. Marketing chaos - when randomness can be deterministic. Journal of International Marketing and Market Research, 16(2):65 - 84.

Hibbert B \& Wilkinson IF. 1994. Chaos Theory and the Dynamics of Marketing Systems. Journal of the Academy of Marketing Science, 22(3):218 - 233.

Holbrook MB. 2003. Adventures in Complexity: Dynamic Open Complex Adaptive Systems, Butterfly Effects, Self-Organizing Order, Coevolution, the Ecological Perspective, Fitness Landscapes, Market Spaces, Emergent Beauty at the Edge of Chaos, and All That Jazz [Online] Available from: www.amsreview.org/articles/holbrook06-2003.pdf [Accessed 2/2/2006].

Hooley G \& Beracs J. 1997. Marketing Strategies for the 21st Century: lessons from the top Hungarian companies. Journal of Strategic Marketing, 5:143-165.

Horovitz B. 2002. Gen Y: A tough crowd to sell. USA Today [Online] Available from: www.usatoday.com/money/covers/2002-04-22-geny.htm [Accessed 29 April 2002]. 
lansiti M. 1995. Managing Product Development in Turbulent Environments. California Management Review, 38(1):36-57.

Johnston RB \& Betts JM. 1996. A Complex Systems Simulation of Planning versus Reacting for Inventory Replenishment [online]. Available from:

http://www.csu.edu.au/ci/vol3/typeset1/typeset1.html [Accessed 18 November 1997].

Kelly S \& Allison MA. 1999. The Complexity Advantage: How the Science of Complexity Can Help Your Business Achieve Peak Performance. New York: BusinessWeek Books.

Koch R. 2000. The Power Laws - The Science of Success. London: Nicholas Brealey.

Kotler P \& Keller KL. 2006. Marketing Management. $12^{\text {th }}$ ed. Upper Saddle River: Pearson Prentice Hall.

Kotter JP. 1996. Kill Complacency. Fortune, 5 August:122-124.

Kumar N, Scheer L \& Kotler P. 2000. From Market Driven to Market Driving. European Management Journal, 18(2):129-141.

Kurtyka J. 2000. Adaptive Marketing: The Changing Relationship of Business to the Customer. Paper read at the International Conference on Complex Systems (ICCS), Nashua, New Hampshire, 22 May, $1-12$.

Lamb CW Jr, Hair JF Jr, McDaniel C, Boschoff C \& Terblanche NS. 2004. Marketing. $2^{\text {nd }}$ ed. Cape Town: Oxford University Press.

Lane D \& Maxfield R. 1996. Strategy under Complexity: Fostering Generative Relationships. Long Range Planning, 29(2):215-231.

Lewin R. 1993. Order for free. New Scientist, 137(1869):10-11.

Loewen J. 1997. The Power of Strategy: A Practical Guide for South African Managers. Sandton: Zebra.

Lynch JE. 1995. Marketing and business process re-engineering. Journal of Marketing Practice: Applied Marketing Science, 1(1):45 - 53.

Manning A. 1991. World Class! Strategies for winning with your customer._. ${ }^{\text {nd }}$ ed. Kenwyn: Juta.

Mason RB. 2004. An investigation into how marketers cope with an environment of high complexity and turbulence, with special reference to the South African environment. Unpublished PhD thesis, Rhodes University, Grahamstown.

Mavondo FT. 1999. Environment and strategy as antecedents for marketing effectiveness and organizational performance. Journal of Strategic Marketing, 7:237-250.

McGlone TA \& Ramsey RP. 1998. Getting Realistic about Reality: Using Chaos Theory to Explain Marketing Phenomena. Proceedings of Society for Marketing Advances conference, New Orleans, 4 7 November 1998.

McKelvey B. 2003. Towards a complexity science of entrepreneurship. Journal of Business Venturing, 19:313-341.

Meade PT \& Rabelo L. 2004. The technology adoption life cycle attractor: Understanding the dynamics of high-tech markets. Technological Forecasting and Social Change, 17:667-684.

Merry U. 1999. Organizational Strategy in Different Landscapes: A New Science Approach. Systemic Practice and Action Research, 12(3):257-278. 
Millier P. 1999. Marketing the unknown: Developing marketing strategies for technical innovations. Chichester: Wiley.

Mintzberg H. 1994. That's not "Turbulence", Chicken Little, Its really opportunity. Planning Review, November-December: 7-9.

Mix RA. 1993. Is there chaos in marketing? Proceedings of Annual Summer Marketing Educators' Conference, American Marketing Association, 444 - 445.

Modis T. 1998. Conquering Uncertainty: Understanding Corporate Cycles and Positioning your company to survive the Changing Environment. New York: McGraw-Hill.

Mohr J. 2001. Marketing of High-Technology Products and Innovations. Upper Saddle River: Prentice Hall.

Morris MH. 1996. The Revolution in Marketing: An Entrepreneurial Perspective. Marketing and Sales Update. November/December: 12-13.

Morrison DJ \& Quella JA. 1999. Pattern thinking: Cutting Through the Chaos. Marketing Management, 8(4):17-23.

Nilson TH. 1995. Chaos Marketing: How to win in a turbulent world. London: McGraw-Hill.

Oliver D \& Roos J. 2000. Striking a balance: Complexity and knowledge landscapes. London: McGraw-Hill.

Palmer A. 1994. Principles of Services Marketing. Maidenhead: McGraw-Hill

Peters EE. 1999. Patterns in the Dark: Understanding Risk and Financial Crisis with Complexity Theory. New York: Wiley.

Peters T. 1987. Thriving on Chaos: Handbook for a management revolution. London: Pan Books.

Phillips F \& Kim N. 1996. Implications of Chaos Research for New Product Forecasting. Technological forecasting and Social Change, 53(3):239-261.

Pine II BJ, Victor B \& Boynton AL. 1993. Making Mass Customization Work. Harvard Business Review, September - October:108-119.

Pitt LF. 1995. Marketing Metamorphosis Revisited. Marketing and Sales Update, September:18-19.

Pitt LF, Berthon PR \& Morris MH. 1997. Entrepreneurial Pricing: the Cinderella of marketing strategy. Management Decision, 35(5):1-8.

Polonsky MJ, Suchard HT \& Scott DR. 1999. The incorporation of an interactive external environment: an extended model of marketing relationships. Journal of Strategic Marketing, 7:41-55.

Prendergast G \& Berthon P. 2000. Insights from Ecology: An Ecotone Perspective of Marketing. European Management Journal, 18(2):223-231.

Priesmeyer HR. 1992. Organizations and Chaos: defining the Methods of Nonlinear Management. Westport: Quorum Books.

Rasmussen DR \& Mosekilde E. 1988. Bifurcations and chaos in a generic management model. European Journal of Operations Research, 35:80-88.

Richardson B. 1996. Synthesis marketing: a shift of the marketing paradigm [online]. Professional Marketing, September [Online] Available from: http://www.scenario-planning.com/archive/art1.htm [Accessed 24 February 1998]. 
Robbins SP. 1990. Organization Theory: Structure, Design and Theory. 3rd Edition. Englewood Cliffs: Prentice Hall.

Roberts JH. 2000. Developing New Rules for New Markets. Journal of the Academy of Marketing Science, 28(1):31-45.

Robertson DA. 2004. The complexity of the corporation. Human Systems Management, 23:71-78.

Saisse MCP \& Wilding RD. 1997. Short-term strategic management in mass customized markets. Logistics Information Management, 10(5):1-7.

Samli AC. 1993. Counterturbulence Marketing: A Proactive Strategy for Volatile Economic Times. Westport: Quorum Books.

Schiller Z, Burns G \& Miller KL. 1996. Make It Simple: That's P \& G's new marketing mantra - and it's spreading. Business Week, 9 September: 96-104.

Siggelkow N \& Rivkin JW. 2005. Designing Organizations for Turbulence and Complexity. Organization Science, 16(2):101-122.

Smith MF, Sinha I, Lancioni R \& Forman H. 1999. Role of Market Turbulence in Shaping Pricing Strategy. Industrial Marketing Management, 28:637-649.

Stacey RD. 1995. The science of complexity: An alternative perspective for strategic change processes. Strategic Management Journal, 16:477-495.

Stacey RD. 1996. Complexity and Creativity in Organizations. San Francisco: Berrett-Koehler. Tedesco Analytics. 2001. Complexity Science and Consumer Decisions [Online] Available from: http://www.TedescoAnalytics.com/content/philosophy/phil.htm [Accessed 25 May 2001].

Tedesco BG. 1998. Neural Network Complexity Models for the Marketing Mix. Paper read at the Advertising Research Foundation Media Accountability Workshop, New York, October 1998.

Thietart R \& Forgues B. 1995. Chaos Theory and Organization. Organization Science, 6(1):19-31.

Thomke S \& Reinertsen D. 1998. Agile Product Development:Managing Development Flexibility in Uncertain Environments. California Management Review, 41(1):8-30.

Turner K \& Williams G. 2004. Modelling complexity in the automotive industry supply chain. Journal of Manufacturing Technology Management, 16(4):447-458.

Van Uden J. 2005. Using complexity science in organization studies: A case for loose application. Using complexity science in organization studies: A case for loose application Issue, Emergence, Complexity \& Organization, 7(1):60-66.

Van Waterschoot W \& Van den Bulte. 1992. The 4P Classification of the Marketing Mix Revisited. Journal of Marketing, 56 October: 83-93.

Vorhies DW. 1998. An investigation of the factors leading to the development of marketing capabilities and organizational effectiveness. Journal of Strategic Marketing, 6:3-23.

Wall SJ \& Wall SR. 1995. The Evolution (Not the Death) of Strategy. Organization Dynamics, Autumn: 7-19.

Wheatley MJ. 1996. The Unplanned Organization. Noetic Sciences Review, Spring:16-23.

Wilding R. 1998. The supply chain complexity triangle: Uncertainty generation in the supply chain. International journal of Physical Distribution and Logistics Management, 28(8):599-616.

Wilkinson I \& Young L. 1998. On Competing: firms, Relations and Networks. Paper read at Research Conference on Relationship Marketing, October 1998, Emory University, 1-27. 
Winsor RD. 1995. Marketing Under Conditions of Chaos: Percolation Metaphors and models. Journal of Business Research, 34:181-189.

Wollin D \& Perry C. 2004. Marketing management in a complex adaptive system: An initial framework. European Journal of Marketing, 38(5/6):556-572.

Yadav N, Swami S \& Pal P. 2006. High Technology Marketing: Conceptualization and Case Study. VIKALPA, 31(2):57-74.

ZeithamI VA \& Bitner MJ. 2003. Services Marketing: Integrating Customer Focus Across the Firm. $3^{\text {rd }}$ ed. New Delhi: McGraw-Hill. 